\title{
Aligning and synchronization of MIS5 proxy records from Lake Ohrid (FYROM) with independently dated Mediterranean archives: implications for DEEP core chronology
}

\author{
Giovanni Zanchetta ${ }^{1}$, Eleonora Regattieri ${ }^{2}$, Biagio Giaccio ${ }^{2}$, Bernd Wagner ${ }^{3}$, Roberto Sulpizio ${ }^{4}$, Alex Francke ${ }^{3}$, \\ Hendrik Vogel $^{5}$, Laura Sadori ${ }^{6}$, Alessia Masi ${ }^{6}$, Gaia Sinopoli ${ }^{6}$, Jack H. Lacey ${ }^{7,8}$, Melanie J. Leng ${ }^{7,8}$, and \\ Niklas Leicher ${ }^{3}$ \\ ${ }^{1}$ Dipartimento di Scienze della Terra, University of Pisa, Pisa, Italy \\ ${ }^{2}$ Institute of Environmental Geology and Geoengineering, IGAG-CNR, Montelibretti, Rome, Italy \\ ${ }^{3}$ Institute of Geology and Mineralogy, University of Cologne, Cologne, Germany \\ ${ }^{4}$ Dipartimento di Scienze della Terra e Geoambientali, University of Bari, Bari, Italy \\ ${ }^{5}$ Institute of Geological Sciences \& Oeschger Centre for Climate Change Research, University of Bern, Bern, Switzerland \\ ${ }^{6}$ Dipartimento di Biologia Ambientale, University of Roma "La Sapienza" Roma, Italy \\ ${ }^{7}$ Centre for Environmental Geochemistry, School of Geography, University of Nottingham, Nottingham, UK \\ ${ }^{8}$ NERC Isotope Geosciences Facilities, British Geological Survey, Keyworth, Nottingham, UK
}

Correspondence to: Giovanni Zanchetta (zanchetta@dst.unipi.it)

Received: 31 August 2015 - Published in Biogeosciences Discuss.: 21 October 2015

Revised: 21 April 2016 - Accepted: 22 April 2016 - Published: 11 May 2016

\begin{abstract}
The DEEP site sediment sequence obtained during the ICDP SCOPSCO project at Lake Ohrid was dated using tephrostratigraphic information, cyclostratigraphy, and orbital tuning through the marine isotope stages (MIS) 151. Although this approach is suitable for the generation of a general chronological framework of the long succession, it is insufficient to resolve more detailed palaeoclimatological questions, such as leads and lags of climate events between marine and terrestrial records or between different regions. Here, we demonstrate how the use of different tie points can affect cyclostratigraphy and orbital tuning for the period between ca. 140 and $70 \mathrm{ka}$ and how the results can be correlated with directly/indirectly radiometrically dated Mediterranean marine and continental proxy records. The alternative age model presented here shows consistent differences with that initially proposed by Francke et al. (2015) for the same interval, in particular at the level of the MIS6-5e transition. According to this new age model, different proxies from the DEEP site sediment record support an increase of temperatures between glacial to interglacial conditions, which is almost synchronous with a rapid increase in sea surface temperature observed in the western Mediterranean. The re-
\end{abstract}

sults show how a detailed study of independent chronological tie points is important to align different records and to highlight asynchronisms of climate events. Moreover, Francke et al. (2016) have incorporated the new chronology proposed for tephra OH-DP-0499 in the final DEEP age model. This has reduced substantially the chronological discrepancies between the DEEP site age model and the model proposed here for the last glacial-interglacial transition.

\section{Introduction}

Since the demonstration of a strong astronomical control on the oxygen isotope composition $\left(\delta^{18} \mathrm{O}\right)$ preserved in the shells of foraminifera collected from marine sediments (e.g. Hays et al., 1976) and the construction of composite reference records (e.g. Martinson et al., 1987; Lisiecki and Raymo, 2005), the marine isotope signal has been extensively used as a reference for chronological tuning of continental successions (e.g Tzedakis et al., 1997, 2001) and to infer, for instance, the response of regional vegetation to climate forcing on a global scale. $\delta^{18} \mathrm{O}$ reference records are of- 
ten based on benthic foraminifera, with appropriate species offset corrections, and are primarily interpreted as first order indicators of global ice volume. Therefore, these records can provide information on glacial-interglacial variations in Earth's climate conditions, even if heavily contaminated by the effect of deep-water temperature variability (e.g. Shackleton, 2000; Skinner and Shackleton, 2006), and by translation these records can also be used for inferring sea-level oscillations (Shackleton, 1987; Waelbroeck et al., 2002).

However, when marine records are used for tuning terrestrial archives there is an implicit assumption of synchronicity between climatic events recognized in marine proxies and those in terrestrial archives, often identified using different proxies. Under scrutiny such a relationship may not be sustainable, as terrestrial and marine proxies could indicate different processes at local and global scales, with different responses to climatic forcing. For instance, marine pollen studies indicate that broad land-sea correlations and average ages of respective stages are generally correct, but that there may be significant offsets in the precise timing of terrestrial and marine stage boundaries (e.g. Shackleton et al., 2003; Tzedakis et al., 2003) when, e.g., pollen and benthic foraminifera $\delta^{18} \mathrm{O}$ were directly compared. These offsets can offer complementary information, which will not be recognized and understood if tuning is the only tool used for chronological control (Blaauw, 2012; Sanchez-Goni et al., 2013). However, correlation between the terrestrial and marine realm is a fundamental task for understanding how climate systems work at different timescales and the nature of climate change impacts on the Earth system.

The development of $U$ / Th-based speleothem studies in the last 20 years may bypass the necessity to synchronize continental archives with marine records for supporting terrestrial chronologies, especially if similar proxies are used (e.g. stable isotopes, Regattieri et al., 2014). Considering that marine chronologies, beyond the limit of radiocarbon dating methods, are often based on astronomical assumptions, it is now also common to transfer independently dated speleothems chronologies to marine records (Bar-Matthews et al., 2000; Almogi-Labin et al., 2009; Drysdale et al., 2007, 2009; Grant et al., 2012; Ziegler et al., 2010; Hodell et al., 2013; Marino et al., 2015; Jiménez-Amat and Zahn, 2015). This can be somewhat problematic, as the assumption of synchronicity between speleothem and marine proxy records is not necessarily straightforward (e.g. Zhornyak et al., 2011). Moreover, different approaches to correlate chronologies from speleothem-based proxy records and marine proxies have been proposed (e.g. Drysdale et al., 2009; Ziegler et al., 2010; Grant et al., 2012; Marino et al., 2015; Jiménez-Amat and Zahn, 2015).

An increasing number of studies are now devoted to the use of tephra layers for correlation and synchronization of archives (see e.g. Lowe, 2011 for an extensive review). In the Mediterranean region, the use of tephra layers as chronological and stratigraphic markers (Wulf et al., 2004, 2008;
Zanchetta et al., 2011, 2012a, b; Blockley et al., 2014; Albert et al., 2015; Giaccio et al., 2015) has largely improved our ability to synchronize archives and proxies, and to recognize leads and lags between different paleoclimate records (e.g. Regattieri et al., 2015). Therefore, the parsimonious use of tuning based on independently dated archives, along with the strong stratigraphic constraint afforded by tephra layers is perhaps the most rigorous way to provide a chronological reference for archives which lack an independent chronology (e.g. Regattieri et al., 2016). However, tephrostratigraphic and tephrochronological work also depends on the accuracy of existing data, and radiometric ages provided for proximal and distal deposition of the same tephra can vary by up to several thousand years. For example the Y-3 tephra is a widespread marker in the central Mediterranean (Zanchetta et al., 2008), for which an age range of ca. 31-30 ka has been proposed for the supposed proximal deposits (e.g. Zanchetta et al., 2008) but this age range has been recently challenged by Albert et al. (2015) who dated distal Y-3 deposits to be between $28.7-29.4 \mathrm{ka}$.

Here we attempt to compare different proxy series from MIS 5 (ca. 130-80 ka; cf. Railsback et al., 2015) from the "DEEP" core composite profile, drilled in Lake Ohrid (Fig. 1) within the framework of the ICDP-SCOPSCO project (Wagner et al., 2014a, b), with recent radiometrically dated continental records in the central Mediterranean, to further constrain the age model of the DEEP record for this period. The major aims are to understand (1) which proxies are most useful for correlating different archives during specific intervals of time; (2) which proxies can provide fundamental information on time-lag relationships between specific environments, and (3) which proxies can be confidently considered as an expression of local-to-regional climatic change. The approach employed here is different from that previously used to produce a chronology for the DEEP site composite long record, which is based on tephrostratigraphy, cyclostratigraphy and/or orbital tuning through the marine isotope record (Baumgarten et al., 2015; Francke et al., 2015, 2016). In contrast, our approach provides more detailed insights into the chronological framework of a discrete time period, and aims to contribute to the synchronization of paleoclimate records in the Mediterranean region.

\section{Site description}

Lake Ohrid originated in a tectonic graben and formed during the latest phases of uplift of the Alps (Stankovic, 1960). It is located on the border between Macedonia (FYROM) and Albania and covers an area of $358 \mathrm{~km}^{2}$ at an altitude of $693 \mathrm{~m}$ a.s.l. (Fig. 1). It is about $30 \mathrm{~km}$ long and $15 \mathrm{~km}$ wide, with a maximum water depth of $293 \mathrm{~m}$ (Lindhorst et al., 2015). The topographic watershed of Lake Ohrid comprises an area of $2393 \mathrm{~km}^{2}$ incorporating Lake Prespa, which is situated $10 \mathrm{~km}$ to the east of Lake Ohrid at an altitude of 


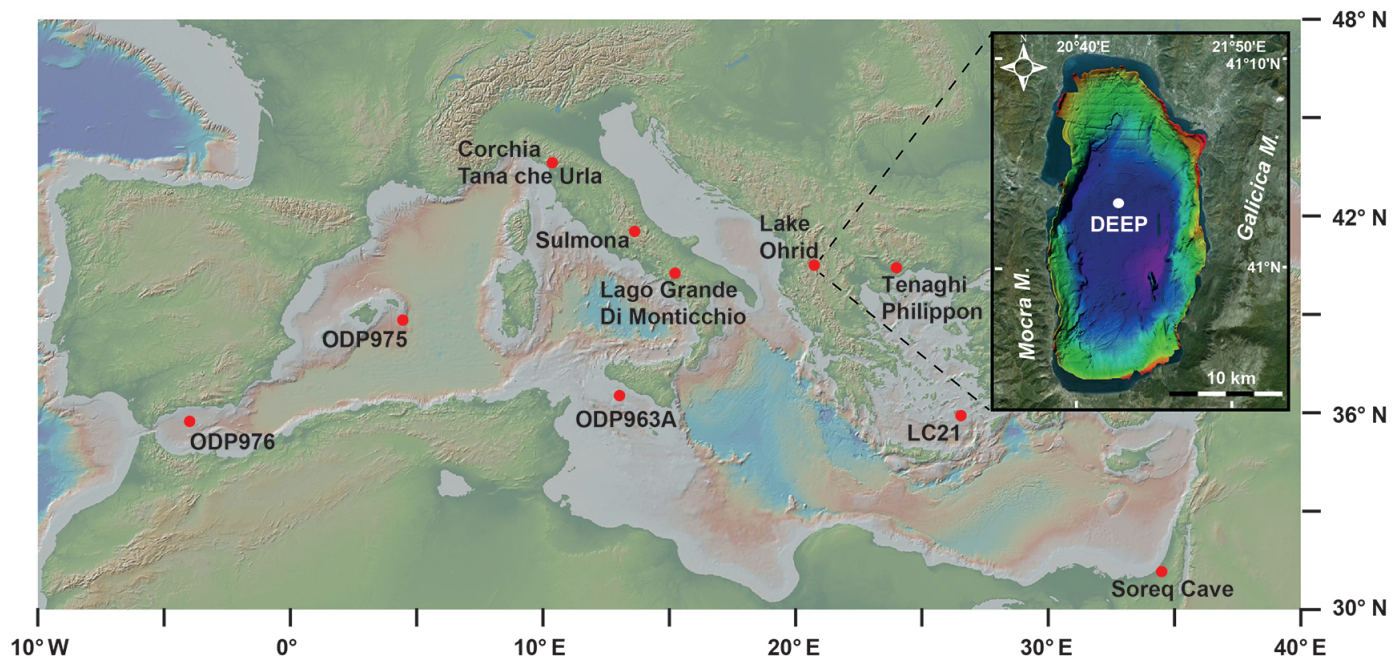

Figure 1. (a) site quoted in the text; (b) DEEP site drilling location within Lake Ohrid.

$848 \mathrm{~m}$ a.s.1. (Popovska and Bonacci, 2007). The two lakes are connected via karst aquifers that pass through the Galičica and Suva Gora mountain ranges. Karst springs depleted in nutrients and minerogenic load represent the primary hydrologic inputs to Lake Ohrid (55\%) and up to $50 \%$ of these karst waters originate from Lake Prespa (Anovski et al., 1992; Matzinger et al., 2007). Direct precipitation on the lake surface, river and direct surface runoff account for the remaining $45 \%$ of the hydrologic input into Lake Ohrid. The surface outflow $(60 \%)$ through the river Crn Drim in the northern corner and evaporation $(40 \%)$ represent the main hydrologic outputs (Matzinger et al., 2006). The theoretical hydraulic water residence time is estimated to be ca. 70 years (Matzinger et al., 2006). Due to its sheltered position in a relatively deep basin surrounded by high mountain ranges and to the proximity of the Adriatic Sea, the climate of the Lake Ohrid watershed shows both Mediterranean and continental characteristics (Watzin et al., 2002). The average annual air temperature for the period between 1961 and 1990 is $+11.1^{\circ} \mathrm{C}$, with a maximum temperature of $+31.5^{\circ} \mathrm{C}$ and a minimum temperature of $-5.7^{\circ} \mathrm{C}$. The average annual precipitation amounts to $800-900 \mathrm{~mm}$ (Popovska and Bonacci, 2007), and the prevailing wind directions follow the N-S axis of the Ohrid valley.

The lake is thought to be the oldest lake in continuous existence in Europe, with current age estimates varying between ca. 1.2 and 5 million years from geological investigations and between 1.5 and 3.0 Ma from molecular clock analyses of endemic taxa (Trajanovski et al., 2010). Preliminary analyses from SCOPSCO DEEP core sediments confirm a limnological age for Lake Ohrid of > 1.2 Ma (Wagner et al., 2014a, b; Baumgarten et al., 2015). The peculiar hydrological conditions of the lake and the presence of $>300$ endemic species make Lake Ohrid a hotspot of biodiversity and a site of global significance (Albrecht and Wilke, 2008; Föller et al., 2015).

\section{Material and methods}

The "DEEP" core was retrieved in the central basin of Lake Ohrid $\left(41^{\circ} 02^{\prime} 57^{\prime \prime} \mathrm{N}\right.$ and $020^{\circ} 42^{\prime} 54^{\prime \prime} \mathrm{E}$, Fig. 1) at $243 \mathrm{~m}$ water depth, in a basement depression with an estimated maximum thickness of sediment fill of $680 \mathrm{~m}$ (Lindhorst et al., 2015). Seismic data show that the upper $\sim 400 \mathrm{~m}$ comprises undisturbed sediments without unconformities or erosional features, thus supporting a continuous sediment record (Wagner et al., 2014a, b). At the DEEP site (ICDP label 5045-1), six parallel holes were drilled to a maximum sediment depth of $569 \mathrm{~m}$ below lake floor (b.l.f.). Pelagic or hemi-pelagic sediments characterize the uppermost $430 \mathrm{~m}$ of the sediment column (Francke et al., 2016). Below $430 \mathrm{~m}$ blf, shallow water facies became increasingly dominant, including peaty layers, coarser sediments with shell remains, and distinct sandy layers. The correlation of the core segments of the individual holes revealed an overall recovery of almost $100 \%$ for the upper ca $248 \mathrm{~m}$ (Francke et al., 2016). Mass movement deposits have thicknesses of $<3 \mathrm{~cm}$, are not erosive, and are very rare in the section studied here, which spans from ca. 53 to 29 metres core composite depth or the period from ca. 140 to $70 \mathrm{ka}$ according to the age model proposed by Francke et al. (2016).

Proxy data used here comprise total inorganic carbon (TIC), total organic carbon (TOC), and biogenic silica (B$\mathrm{SiO}_{2}$ ) from Francke et al. (2016), the stable isotope composition of total inorganic carbon $\left(\delta^{18} \mathrm{O}_{\mathrm{TIC}}\right.$ and $\left.\delta^{13} \mathrm{C}_{\mathrm{TIC}}\right)$ from Lacey et al. (2016) and pollen data from Sadori et al. (2016). Analytical procedure and related errors, in addition to individual sampling resolutions, are discussed in the cited papers. $\delta^{18} \mathrm{O}_{\text {TIC }}$ and $\delta^{13} \mathrm{C}_{\text {TIC }}$ data are present only between 128 and $78 \mathrm{ka}$, where there was sufficient TIC for isotope analysis (Lacey et al., 2016). The investigated interval includes three prominent tephra layers, which were visually identified af- 


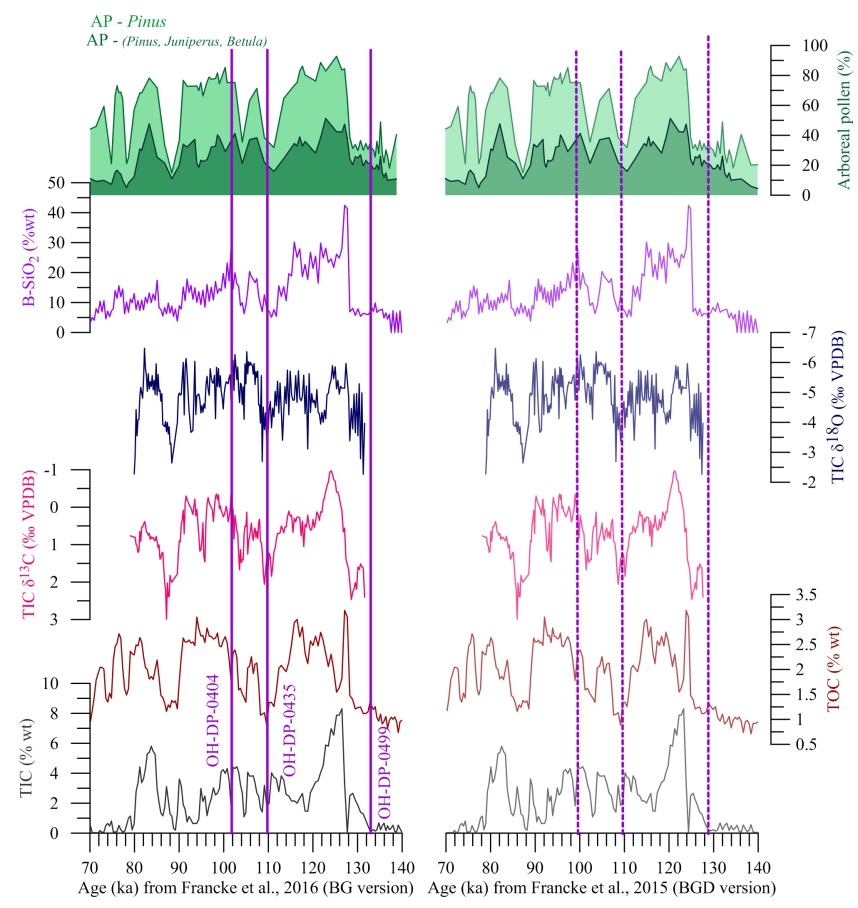

Figure 2. DEEP site proxy series plotted on age models from Francke et al., 2016 (left) and Francke et al. (2015; right). From top: B-SiO 2 after Francke et al. (2016), AP \% (Arboreal Pollen, without considering Pinus spp. pollen grains) after Sadori et al., 2016; TIC $\delta^{13} \mathrm{C}$ after Lacey et al. (2016); TIC $\delta^{18} \mathrm{O}$ after Lacey et al. (2016); TOC and TIC \% after Francke et al. (2016). Violet lines indicate tephra layers.

ter core opening and are characterized by prominent peaks in XRF-scanning data (Francke et al., 2016). A detailed description of these tephra layers, as well as analytical procedures for their geochemical fingerprinting, can be found in Leicher et al. (2016). Most of these tephras have already been described for other cores from Lake Ohrid and nearby Lake Prespa (Lezine et al., 2010; Wagner et al., 2008; Sulpizio et al., 2010a, b; Vogel et al., 2010; Damaschke et al., 2013). In Fig. 2 all Lake Ohrid data are plotted versus the age, according to the model established by Francke et al. (2016). Other Mediterranean records (Fig. 3) are plotted using their own published age models. Correlation with MISs is given but acknowledged to be likely inaccurate as there may not necessarily be an identical correspondence between marine and terrestrial proxies. Moreover, we use the term "transition" instead of "termination" for the passage between glacial and interglacial periods, as suggested by Kukla et al. (2002), because the definition of "termination" should be reserved for benthic isotopic records where it has been defined (e.g. Broecker and van Donk, 1970). Govin et al. (2015) have recently suggested to use the term "penultimate deglaciation" to refer to the climatic transition occurring between full glacial and interglacial conditions. The two terms are often used interchangeably. Following the definition of Govin et al. (2015) our approach is to align the $\delta^{18} \mathrm{O}$ records at the regional scale. However, according to Govin et al. (2015), the term "synchronization" should be used when tephra layers are used. Therefore, in our tuning exercise here proposed, we align using regional proxies and we synchronize using tephra layers.

\section{Results and discussion}

Figure 2 shows the correlation of selected proxy series from the DEEP site. The general structure of the different proxies shows a relatively good agreement, as already discussed in other contributions of this themed issue (Francke et al., 2016; Lacey et al., 2016; Just et al., 2016). Interglacial sediments are typically characterized by calcareous and slightly calcareous silty clay, while clastic, silty clayey material dominates in the glacial periods (Francke et al., 2016). However, although orbital-scale sedimentological variability and sedimentation rates appear to remain fairly constant, differences are apparent when the cores are examined at higher resolution. The transition between MIS6 and the Last Interglacial (i.e., MIS5e) is of particular interest. In the original Biogeosciences Discussion paper by Francke et al. (2015) the age model used for the DEEP site assumed an age of $129 \pm 6 \mathrm{ka}$ for the tephra layer OH-DP-0499, which was correlated to P11 tephra (Rotolo et al., 2013; Leicher et al., 2016) and used as 1st order independent chronological tie point (cf., Francke et al., 2016). Using this model, all the proxy data show a prominent change starting at ca. 124-125 ka (Fig. 2a). $\delta^{18} \mathrm{O}_{\text {TIC }}$ shows decreasing values starting at ca. $128 \mathrm{ka}$, followed by a second, more pronounced step from ca. 124$125 \mathrm{ka}$ (Fig. 2a). TIC percentage starts to increase almost synchronous to the first $\delta^{18} \mathrm{O}_{\text {TIC }}$ step, but with a prominent rate of increase from ca. $125 \mathrm{ka}$. TOC shows a similar pattern, but with a slightly earlier and more gradual increase (Francke et al., 2015, 2016). The behaviour of these three proxies can be explained by an initial step of warming at the end of the glaciation, with an increase of primary productivity possibly connected with a change in the efficiency of recycling of organic matter within the lake (e.g. burial vs. bottom oxygenation). This early signal of warmer temperature is also confirmed by $\delta^{13} \mathrm{C}_{\text {TIC }}$, which shows a small decrease at the same time TIC percentage begins to increase, and by pollen data, which shows a synchronous small increase of arboreal pollen percentage (AP \%; Fig. 2). Interestingly, TIC percentage and isotopes show a short inversion just before the start of the second prominent step (Fig. 2). This second step is also well marked by a strong increase in $\mathrm{B}-\mathrm{SiO}_{2}$, indicating a definite transition to interglacial conditions.

The comparison of DEEP proxy data during the MIS6MIS5 transition with regional records (Fig. 3) shows some interesting features, which highlight the timing and evolution of the glacial/interglacial transition at Lake Ohrid and may represent the starting point for tuning consideration. 


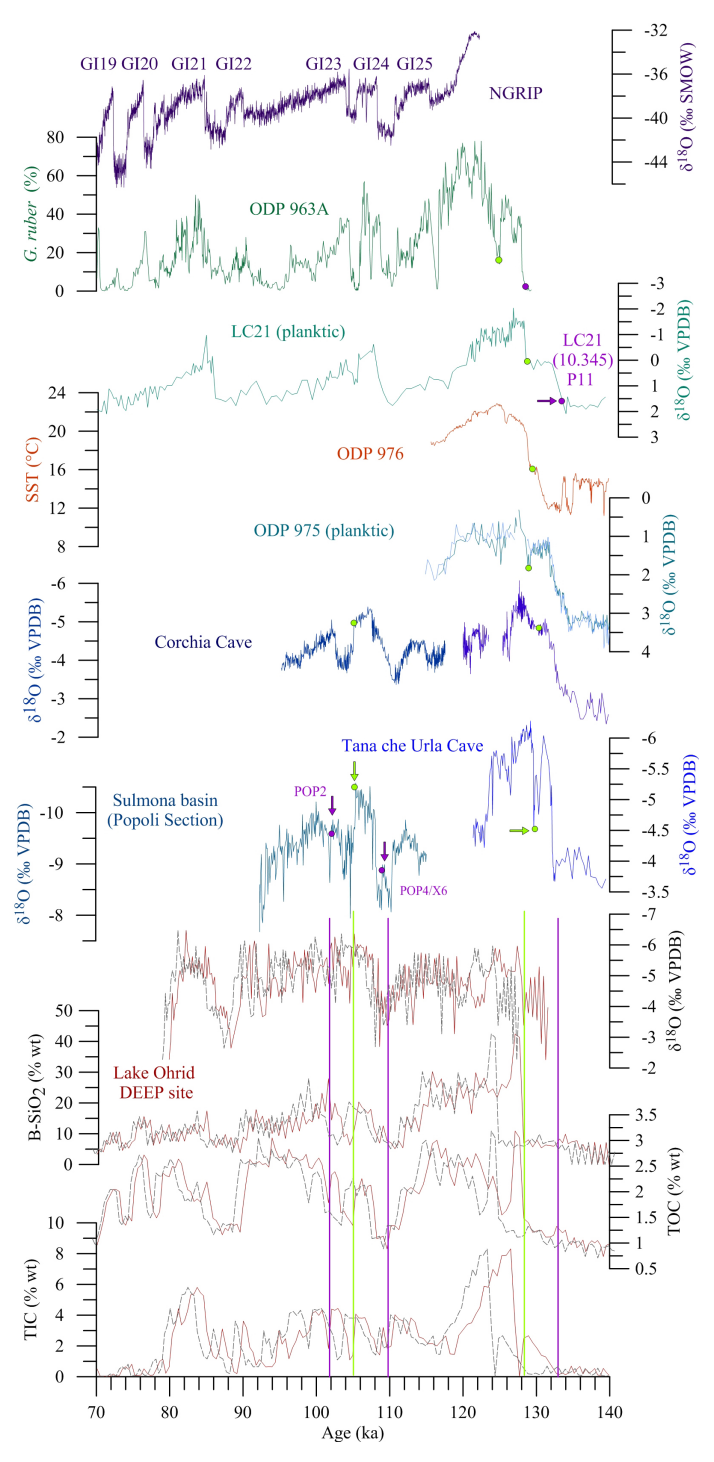

Figure 3. Comparison of selected DEEP proxies (TIC $\delta^{18} \mathrm{O}$ after Lacey et al. (2016), B-SiO 2 after Francke et al. (2016), TOC and TIC \% after Francke et al., 2016) with regional to extra regional record. From the bottom: $\delta^{18} \mathrm{O}$ from Sulmona paleolake (POP section, Regattieri et al., 2015); $\delta^{18} \mathrm{O}$ from Corchia Cave (CC5 Drysdale et al., 2009; CC28 Drysdale et al., 2007) and Tana che Urla Cave (Regattieri et al., 2014); ODP-975 planktic $\delta^{18} \mathrm{O}$ (G. ruber darker; G. bulloides, lighter, after Marino et al., 2015); ODP-976 Alkenone SST (data from Martrat et al., 2014 and age model after Marino et al., 2015); LC21 planktic $\delta^{18} \mathrm{O}$ (G. bulloides Grant et al., 2012); ODP-963A G. ruber abundance (Sprovieri et al., 2006); $\delta^{18}$ O from NGRIP ice core (NGRIP member, 2004). Violet dots indicates correlated tephra layers (LC21 10.345/P11 on core LC2 1 and ODP-963A, POP2 and POP4/X6 on Sulmona Basin $\delta^{18} \mathrm{O}$ record, Regattieri et al., 2015); green dots indicate correlated points used for tuning. Arrows and lines (violet $=$ tephras, green $=$ tuning point) indicate age tuning points. See text and Table 1 for details. Dotted lines are the same proxies, but plotted using the Franke et al. (2015) age model.
A majority of Mediterranean $\delta^{18} \mathrm{O}$ planktonic records show a two-stepped MIS6-MIS5 transition (e.g. Paterne et al., 2008; Grant et al., 2012; Martrat et al., 2014; Marino et al., 2015 and references therein). Figure 3 shows data from site ODP-975 compiled by Marino et al. (2015). In Marino et al. (2015), the well-documented intermediate-water connection between the eastern and western Mediterranean Sea allowed for the ODP-975 $\delta^{18} \mathrm{O}$ planktonic record to be tuned with the $\delta^{18} \mathrm{O}$ planktonic record of the LC21 core in Eastern Mediterranean (Marino et al., 2015; Figs. 1, 3). LC21 had previously been chronologically anchored to Soreq cave $\mathrm{U} / \mathrm{Th}$ speleothem chronology, based on the assumption that speleothem $\delta^{18} \mathrm{O}$ from Soreq Cave strictly reflects changes in the isotopic composition of the eastern Mediterranean surface water (Bar-Matthews et al., 2003; Grant et al., 2012). Marino et al. (2015) subsequently propagated the ODP975/LC21 chronology to the core ODP-976, producing an Alkenone Sea Surface Temperature (SST) record starting from the data obtained by Martrat et al. (2014; Figs. 1, $3)$. Therefore, planktonic $\delta^{18} \mathrm{O}$ records of LC21 and ODP975 and SST from ODP-976 are all anchored to the same chronologies derived by tuning with Soreq Cave speleothems (Grant et al., 2012; Marino et al., 2015).

A similar two-stepped pattern for the MIS6-MIS5 transition is also observed in $\delta^{18} \mathrm{O}$ of two well-dated speleothems from the Apuan Alps in central Italy (Fig. 1) collected in the Corchia and Tana che Urla caves (Drysdale et al., 2009; Regattieri et al., 2014). A potential tie point for tuning between the DEEP site and these speleothem records is represented by a small inflection that is evident in the DEEP $\delta^{18} \mathrm{O}_{\text {TIC }}$ data (green line in Fig. 3), in both speleothem $\delta^{18} \mathrm{O}$ series (Tana Che Urla and Corchia) and in LC21 and ODP975 $\delta^{18} \mathrm{O}$ planktonic records (green dots in Fig. 3). The end of this inflection is easily identifiable and robustly $U / T h$ dated at Tana che Urla at $129.6 \pm 0.9 \mathrm{ka}$ (Regattieri et al., 2014). The use of this tie point for the DEEP core would have several important implications. Firstly, the old DEEP age model of Francke et al. (2015) underestimated the chronology of the transition by ca. 4-5 ka. Secondly, the distinct step recorded by all the DEEP proxies at $124 \mathrm{ka}$ (Fig. 2) would coincide with the phase of highest rate of rising temperature recorded in the Western Mediterranean, according to the new chronology for ODP-976 SST record (Marino et al., 2015; Figs. 3, 4). Therefore, aligning the DEEP time series with other Mediterranean chronologies indicates that the rapid temperature increase observed at ca. 129-128 ka in the SST of ODP-976 is almost coincident to the sharp increase in $\mathrm{TIC} \%$, TOC $\%, \mathrm{AP} \%$, and $\mathrm{B}-\mathrm{SiO}_{2}$ values and to the sharp decrease in $\delta^{13} \mathrm{C}_{\text {TIC }}$ and $\delta^{13} \mathrm{C}_{\mathrm{TOC}}$ (Fig. 4).

To strengthen the proposed correlation of events during the MIS6-5e transition, we also consider the position of the tephra layer P-11 from Pantelleria Island in different records (Fig. 3, red dots; Paterne et al., 2008; Caron et al., 2010; Vogel et al., 2010), which is correlated with the tephra layer OH-DP-0499 recognized in the DEEP core (Leicher et al., 


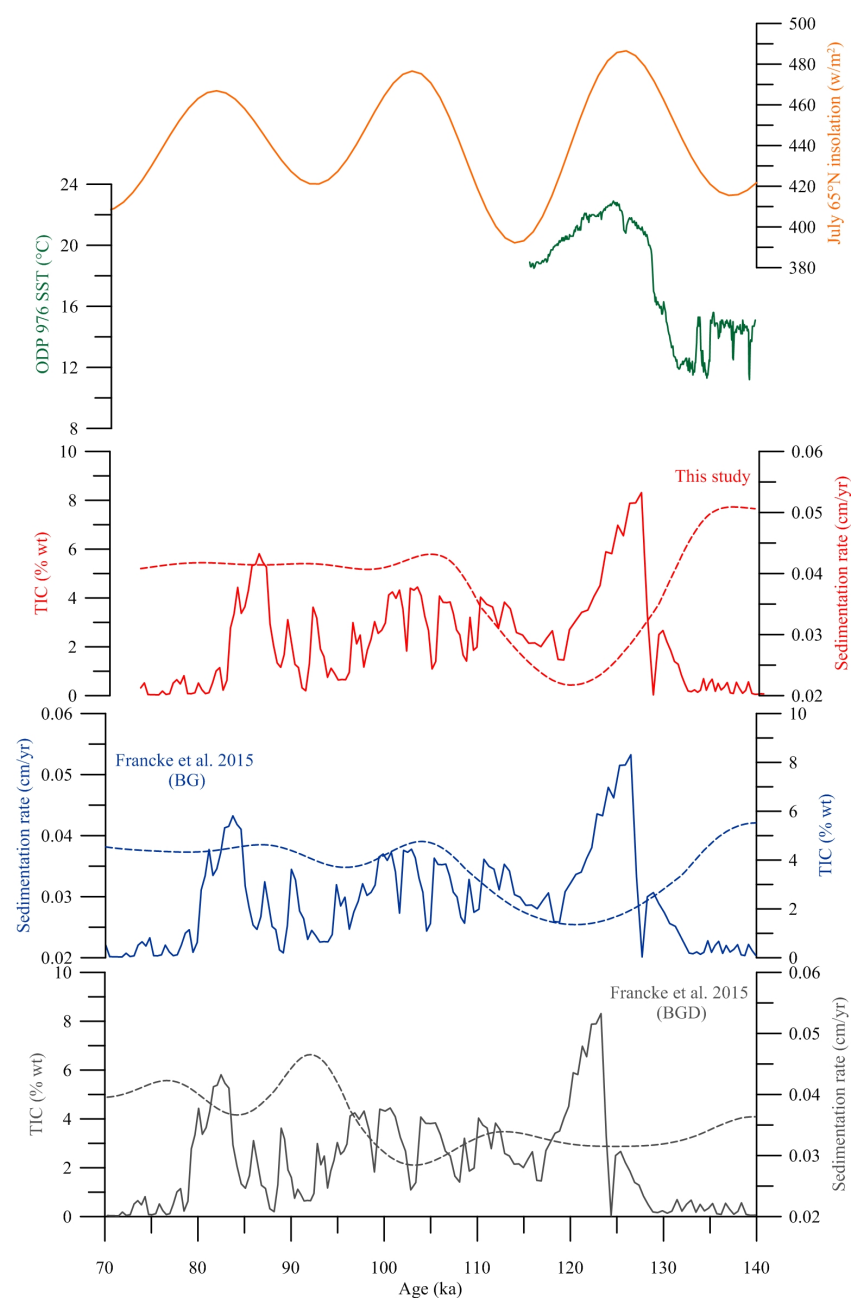

Figure 4. From bottom: TIC (\% wt) and sedimentation rate of DEEP site plotted on age models from Francke et al. (2015, Discussion version, grey); Francke et al. (2016, blue); this study (red); Alkenone SST $\left({ }^{\circ} \mathrm{C}\right.$ ) for core ODP-976 (Marino et al., 2015, green); Summer (July) insolation at $65^{\circ} \mathrm{N}$ (orange; Berger and Loutre, 1991).

2016; Fig. 2). As shown in Fig. 3, this tephra layer occurs at the base of the first small, but pronounced, increase of TIC in the Ohrid record. In the ODP-963A record from the central Mediterranean (Fig. 3; Sprovieri et al., 2006; Tamburrino et al., 2012) this tephra layer (here correlated with ODP3 layer) corresponds to the first increase in the abundance of Globigerinoides ruber (a warm foraminifera taxa) after the end of MIS6. In core LC21 from the eastern Mediterranean, a pantelleritic tephra (Satow et al., 2015) was found at the beginning of the first decrease of G. ruber $\delta^{18} \mathrm{O}$ (Fig. 3). This also corresponds to the position of $\mathrm{P}-11$ in the $\delta^{18} \mathrm{O}$ G. bulloides record from core KET82-22 in the Ionian Sea (Paterne et al., 2008), although this record has a low resolution compared to LC21. Overall, P-11 occupies the same "climatostratigraphic" position in every one of these records. According to the speleothem-based chronology proposed for core LC21, the Pantelleritic layer was dated at ca. 133.5 $\pm 2 \mathrm{ka}$ (Grant et al., 2012; Satow et al., 2015). This would be slightly older (although statistically indistinguishable) compared to the age reported from the Unit $\mathrm{P}$ at Pantelleria (ca. $129 \pm 6 \mathrm{ka}$, Rotolo et al., 2013), which is regarded as proximal counter part of this tephra layer (Paterne et al., 2008) and that was used for the first age model of the DEEP core (Francke et al., 2015). This age represents an average over different sets of dating, and thus has a large error (Rotolo et al., 2013). However, we have to note that even if the stratigraphic correlation between P-11 and the pantelleritic layer in LC21 is obvious, chemical data used for tephrostratigraphy are not unambiguous and could indicate a different dispersion of ash with different chemistry, as result of a zoned magma chamber (Leicher et al., 2016). Taking these considerations into account, it seems reasonable to shift the age model for the MIS6-MIS5e transition at the DEEP site by ca. 4 ka compared to Francke et al. (2015). This shift is supported by a marked increase in the abundance of G. ruber in ODP-963A, immediately following the P-11 tephra (Fig. 3), which is indicative of warming conditions and probably correlates with the initial TIC increase observed in the DEEP site record. Following the revision proposed here, which substantially differs from the approach used by Francke et al. (2015), Francke et al. (2016) changed the age of OH-DP-0499 tephra to that of Satow et al. (2015), which alleviated the discrepancies between the two age models for the period corresponding to the penultimate deglaciation (Fig. 4).

In the central Mediterranean, and specifically for Corchia and Tana che Urla caves, speleothem calcite $\delta^{18} \mathrm{O}$ is principally seen as an indicator of local hydrology and interpreted in terms of "amount of precipitation", with lower/higher values related to increasing/decreasing precipitation (Bard et al., 2002; Drysdale et al., 2004, 2005, 2006, 2007, 2009; Zanchetta et al., 2007, 2014; Regattieri et al., 2014). Changes in precipitation amount, and thus in $\delta^{18} \mathrm{O}$ of speleothem, have in turn been linked to North Atlantic conditions, with enhanced ocean evaporation and advection toward the Mediterranean (i.e. higher rainfall) during periods of higher ocean SST (e.g. Drysdale et al., 2004). Similar findings have also been found in lake $\delta^{18} \mathrm{O}$ records (Regattieri et al., 2015, 2016; Giaccio et al., 2015). Based on such evidence, the first decreasing in the $\delta^{18} \mathrm{O}_{\mathrm{TIC}}$ values of the DEEP record may also be related to increasing precipitation. However, Marino et al. (2015) proposed that the first $\delta^{18} \mathrm{O}$ decrease in both Mediterranean planktonic foraminifera and speleothems is instead related to a decreasing sea surface salinity (SSS), due to massive iceberg discharge related to Heinrich event 11 (H11), a major deglacial meltwater pulse that may account for about $70 \%$ of the glacial-interglacial sea-level rise. If this is correct then the prominent shift in the $\delta^{18} \mathrm{O}_{\text {TIC }}$ of the DEEP record at the beginning of the transition is likely related to the progressive lowering of sea surface isotopic com- 
position due to decreasing SSS (i.e. source effect) and not to hydrological changes (i.e., increasing of precipitation).

The designation of additional tuning points during the interglacial appears more complicated. During the first part of MIS5e some common patterns are evident, like the prominent increase in TIC, TOC and $\mathrm{B}-\mathrm{SiO}_{2}$ between ca 124 and $120 \mathrm{ka}$. We suggest that a good correlation point would be the sharp increase in $\delta^{18} \mathrm{O}$ at the transition between GI24 and GS23 visible at Corchia and the DEEP core (Fig. 3, green dots), as well as in the $\delta^{18} \mathrm{O}$ record from lacustrine carbonate from the Sulmona basin (POP section, Regattieri et al., 2015). This point is set at ca. $105.1 \mathrm{ka}$ in the CC28 stalagmite record from Corchia Cave (Drysdale et al., 2007) and it is chronologically in agreement with data from the POP section (Figs. 1, 3, Regattieri et al., 2015) and NALPS speleothem records from the northeastern Alps (Boch et al., 2011). We note that the increase in $\delta^{18} \mathrm{O}$ slightly precedes the TIC, TOC, and $\mathrm{B}-\mathrm{SiO}_{2}$ decrease. We are not able to give a detailed explanation for this, but we believe that it is more appropriate to use the $\delta^{18} \mathrm{O}_{\mathrm{TIC}}$ when tuning with other $\delta^{18} \mathrm{O}$ records (speleothem and lacustrine). As discussed, we are aware by the fact that $\delta^{18} \mathrm{O}$ in speleothems and lacustrine sediments can be affected by several local factors (e.g. Wilson et al., 2015) and unequivocal paleoclimatic interpretation may complicate the use of this proxy for "synchronization" studies (Govin et al., 2015), but the consistent nature of the $\delta^{18} \mathrm{O}$ signal observed in different regional archives (e.g. speleothems and lacustrine carbonate) makes the use of $\delta^{18} \mathrm{O}$ of carbonate a good candidate for the alignment of the discussed records.

Two robust target points for synchronization are represented by the tephra layers OH-DP-0404 and OH-DP-0435 (Fig. 2), which were independently dated in other records (Table 1). Particularly, both tephras occur in the POP section from the Sulmona Basin (Regattieri et al., 2015) and thus their recalculated ages can be obtained from this age model. Tephra OH-DP-0435 is also used in Francke et al. (2015, 2016) as tie point, and the ${ }^{40} \mathrm{Ar} /{ }^{39} \mathrm{Ar}$ radiometric age from Iorio et al. (2014) was used.

From the above discussion, we suggest an alternative age model for the MIS 5 DEEP record (Fig. 4) using the tie points shown in Fig. 3 (green and purple arrows) and detailed in Table 1. This new age model was calculated using the Bacon software (Blaauw, 2011), using the same settings employed also for the construction of the DEEP site chronology by Francke at al. (2016). The simulation is limited to the chronological interval for which tie points are available (ca. 140-70 ka).

As noted before, the most significant differences are in the timing of the whole glacial/interglacial transition in the first age model of Francke et al. (2015). However, in the final version of the age model from Francke et al. (2016), incorporating the new age here proposed for the OH-DP-0499 tephra layer, the differences are less evident (Fig. 4). There is a good fit between ca. 115 and 108 and ca. 95-88 ka, whereas ages

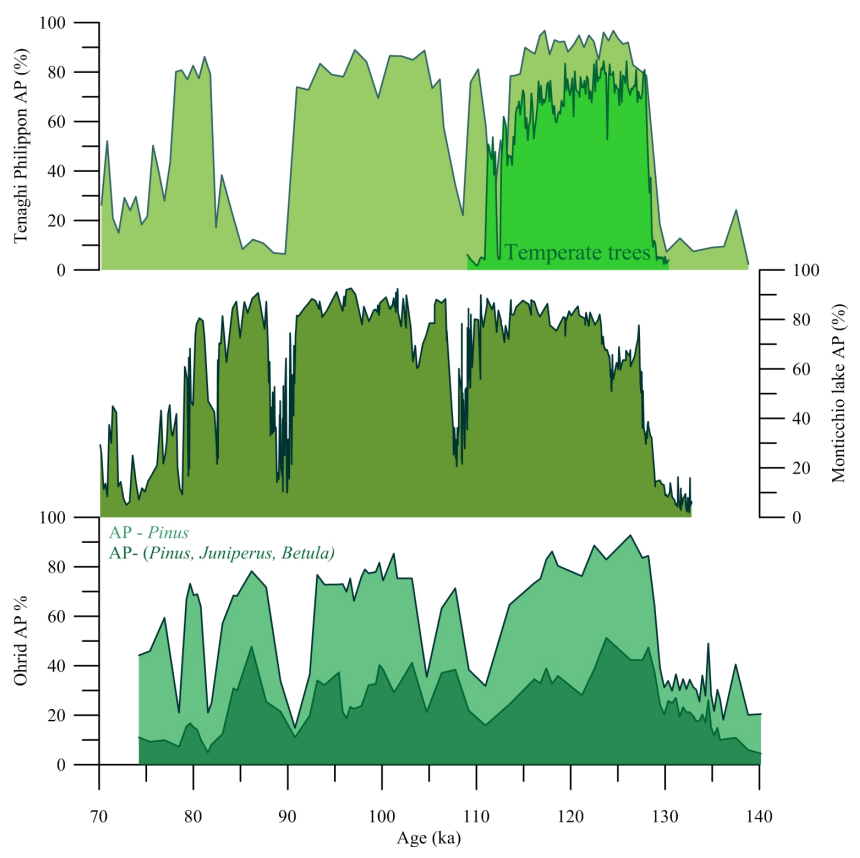

Figure 5. From bottom: DEEP site pollen record (AP-Pinus and AP-(Pinus, Betula and Juniperus), Sadori et al., 2016) plotted on chronology proposed in this study; Monticchio Lake arboreal pollen (Brauer et al., 2007); Tenaghi Philippon, \% of temperate trees from Milner et al. (2012) and total AP from Tzedakis et al. (2006).

diverge again at the base of the record. Interestingly, the new model allows for comparison between the Ohrid record and with SST reconstructions from the Western Mediterranean (core ODP-975), which, as previously explained, is an indirectly, radiometrically dated record (Fig. 4). Despite a minor chronological offset, the pattern of TIC variability during the transition is consistent with that of SST.

Figure 4 also illustrates the change in sedimentation rate in the different age models. It is possible to see that by increasing the number of aligning points the sedimentation rate becomes significantly different, suggesting a faster decrease at the time of the interglacial inception. Sedimentation rate increased again around $120 \mathrm{ka}$, and then remained stable since ca. $105 \mathrm{ka}$. We note that the Francke et al. (2016) age model (and most other age models too) are based on the assumption of gradually changing sedimentation rates. This might be true if studying long sequences at low resolution. However, changes in sedimentation rates become more important when examining a sequence at higher resolution. On the long-term scale, and using the chronological tie points of the 11 tephras from the orbital tuning used in the Francke et al. $(2015,2016)$ age model, relatively constant sedimentation rates are inferred for the DEEP core site record. On closer inspection, however, there might be significant changes, particularly at the MIS6-5e transition, as inferred from the new age model (see also Francke et al., 2016), as it is highly unlikely that a decrease in clastic input from the catchment (prevailing 
Table 1. Chronological tie points discussed in this study. DEEP core ages and associated $2 \sigma$ uncertainties are from Francke et al. (2015, Discussion AM) and Francke et al. (2016, Final AM) age models.

\begin{tabular}{|c|c|c|c|c|c|c|c|c|c|c|c|c|}
\hline & & \multirow[b]{3}{*}{ mod depth } & \multicolumn{4}{|c|}{ DEEP core age model } & \multicolumn{4}{|c|}{ This study } & & \\
\hline & & & \multicolumn{2}{|c|}{ Final AM } & \multicolumn{2}{|c|}{ Discussion AM } & \multicolumn{2}{|c|}{ New used age } & \multicolumn{2}{|c|}{ New modelled age } & \multicolumn{2}{|c|}{ Age differences } \\
\hline \multicolumn{2}{|c|}{ tuning points } & & $\begin{array}{l}\text { Age } \\
(\mathrm{ka})\end{array}$ & $\begin{array}{r}2 \sigma \\
(\mathrm{ka})\end{array}$ & age & $\begin{array}{r}2 \sigma \\
(\mathrm{ka})\end{array}$ & $\begin{array}{l}\text { Age } \\
\text { (ka) }\end{array}$ & $\begin{array}{r}2 \sigma \\
(\mathrm{ka})\end{array}$ & $\begin{array}{l}\text { Age } \\
(\mathrm{ka})\end{array}$ & $\begin{array}{r}2 \sigma \\
(\mathrm{ka})\end{array}$ & Final & Discussion \\
\hline tephra & POP2 & 40.49 & 101.8 & 2.4 & 99.2 & 3.2 & $102.0^{\mathrm{d}}$ & 2.4 & 103.6 & 3 & -1.8 & -1.8 \\
\hline tuning & end GI24 & 41.63 & 104.8 & 4.2 & 103.1 & 3.6 & $105.4^{\mathrm{c}}$ & 0.9 & 105.4 & 1.8 & -0.6 & -2.3 \\
\hline tephra & POP4 & 43.51 & 109.8 & 2.0 & 109.7 & 2 & 109 & 1.5 & 109.7 & 2.4 & 0.1 & 0 \\
\hline tuning & TII TCU & 48.58 & 127.7 & 6.6 & 124.4 & 2.7 & $129.6^{\mathrm{b}}$ & 0.9 & 129.4 & 2 & -1.7 & -5 \\
\hline tephra & $\mathrm{P} 11$ & 49.94 & 133.0 & 2.0 & 129.4 & 6 & $133.5^{\mathrm{a}}$ & 2.0 & 132.7 & 2.7 & 0.3 & -3.3 \\
\hline
\end{tabular}

${ }^{a}$ From Satow et al. (2015; after Grant et al., 2012), ${ }^{\mathrm{b}}$ from Tana che Urla record (Regattieri et al., 2014), ${ }^{\mathrm{c}}$ from Popoli section record (Regattieri et al., 2015), ${ }^{\mathrm{d}}$ from Corchia Cave CC28 record (Drysdale et al., 2007).

during glacials, even if partially compensated by a reduced input of organic matter and calcite, and indicated in lithofacies 3 of Francke et al., 2016) is completely, simultaneously and equally compensated by an increase in carbonate precipitation reaching $>80 \%$ during the interglacial (MIS 5e peak, Fig. 4). This means that it is highly likely that there are significant changes in sedimentation rates, which can only be detected by high resolution studies and by a detailed comparison of different records, as indicated in this study.

From Fig. 4 it is also possible to note that the strong increase in SST and TIC occurred slightly before the maximum of summer insolation at $65^{\circ} \mathrm{N}$; when the insolation reached its maximum TIC starts to decrease, whereas SST reaches its maximum. A secondary maximum in TIC occurs at ca. $86 \mathrm{ka}$, ca. $4 \mathrm{ky}$ before the maximum in insolation, whereas the decrease starts at the maximum of insolation.

With the new age model presented here it is also possible to attempt a more precise regional correlation of pollen records. In Fig. 5 pollen records from Tenaghi Philippon, (Fig. 1, Milner et al., 2012, 2013; Pross et al., 2015) and Monticchio (Fig. 1; Brauer et al., 2007) are plotted against the DEEP site pollen record (Sadori et al., 2016). The sharp increase in the AP percentages at ca. $130 \mathrm{ka}$ is almost synchronous in all the mentioned records, and simultaneous to the highest rate of SST increase in the western Mediterranean (Fig. 4). A comparison of the chronology from different records after the end of the Eemian forest phase is more problematic, since the first clear forest opening coincides with the C24 cold event in the North Atlantic (SánchezGoñi et al., 1999). In the DEEP core, two tephra layers and a robust alignment point at the end of GI24 probably make this chronology the most reliable, even if in the younger part of the record there are no further alignment points.

The proposed correlation exercise described here can potentially be extended in the future to other sections of the DEEP record. The $\delta^{18} \mathrm{O}_{\mathrm{TIC}}$ and TIC data contain interesting points for tuning, even if correlations with regional records are not always obvious. However, both have limitation be- cause TIC is particularly low or absent during most of the glacial periods (Lacey et al., 2016; Francke et al., 2016) and seems to be affected by dissolution once a critical threshold is exceeded. Because of preservation/dissolution processes during glacial periods (Lacey et al., 2016; Francke et al., 2016) the selection of correlation points at the beginning of the glacial/interglacial transition would be complex. Moreover, the interglacial periods seem the more appropriate periods for applying the approach presented here. Therefore, a careful selection between proxy data is necessary, because leads and lags are evident when the fine scale is considered. However, the DEEP multiproxy record, along with the presence of regionally important tephra layers, allow us to apply a range of alignment and synchronization approaches.

\section{Conclusions}

Regional proxy records that have been independently dated support the development of a more detailed chronology for the Lake Ohrid DEEP site record in the interval covering the MIS6/5 transition and the first part of MIS5. The aligning with regional proxies indicates that the most prominent rate of increase of $\mathrm{B}-\mathrm{SiO}_{2}$, TIC, TOC, $\mathrm{AP} \%$, and $\delta^{13} \mathrm{C}_{\mathrm{TOC}}$ is concomitant with increasing in temperature in Western Mediterranean cores (Figs. 3, 4), whereas $\delta^{18} \mathrm{O}_{\mathrm{TIC}}$ and TIC seem also to record an early warming, probably connected with hydrological changes (increasing rainfall). $\delta^{18} \mathrm{O}_{\mathrm{TIC}}$ may also record a source change in the isotopic composition of oceanic surface waters due to a massive discharge of freshwater resulting from the H11 event (Marino et al., 2015).

During the MIS5 interglacial, different proxy records show generally similar patterns but with evident leads and lags, which can make the selection of the tuning points somewhat more complex. However, the presence of two regionally widespread tephra layers allows a relatively good anchoring of the chronology. 
It is important to remark that the approach proposed here can be extended to relatively few intervals of the long DEEP record because independently radiometrically dated records in the Mediterranean region are rare for periods older than the MIS5 (e.g. Bar-Matthews et al., 2000; Drysdale et al., 2004; Giaccio et al., 2015; Regattieri et al., 2016). Therefore, the approach proposed by Baumgarten et al. (2015) and Francke et al. (2016) still appears the most suitable for the definition of general chronological framework of the long record.

Acknowledgements. The SCOPSCO Lake Ohrid drilling campaign was funded by ICDP, the German Ministry of Higher Education and Research, the German Research Foundation, the University of Cologne, the British Geological Survey, the INGV and CNR (both Italy), and the governments of the republics of Macedonia (FYROM) and Albania. Logistic support was provided by the Hydrobiological Institute in Ohrid. Drilling was carried out by Drilling, Observation and Sampling of the Earth's Continental Crust's (DOSECC) and using the Deep Lake Drilling System (DLDS). Special thanks are due to Beau Marshall and the drilling team. Ali Skinner and Martin Melles provided immense help and advice during logistic preparation and the drilling operation. We thank two anonymous reviews for the constructive comments and criticisms, which improved the quality of the manuscript.

Edited by: F. Wagner-Cremer

\section{References}

Albert, P. G., Hardiman, M., Keller, J., Tomlinson, E. L., Smith, V. C., Bourne, A. J., Wulf, S., Zanchetta, G., Sulpizio, R., Müller, U. C., Pross, J., Ottolini, L., Matthews, I. P., Blockley S. P. E., and Menzies, M. A.: Revisiting the Y-3 tephrostratigraphic marker: a new diagnostic glass geochemistry, age estimate, and details on its climatostratigraphical context, Quaternary Sci. Rev., 118, 105-121, doi:10.1016/j.quascirev.2014.04.002, 2015.

Albrecht, C. and Wilke, T.: Lake Ohrid: Biodiversity and evolution, Hydrobiologia, 615, 103-140, 2008.

Almogi-Labin, A., Bar-Matthews, M., Shriki, D., Kolosovsky, E., Paterne, M., Schilman, B., Ayalon, A., Aizenshtat, Z., and Matthews, A.: Climatic variability during the last $90 \mathrm{ka}$ of the southern and northern Levantine Basin as evident from marine records and speleothems, Quaternary Sci. Rev., 28, 2882-2896, 2009.

Anovski, T., Andonovski, B., and Minceva, B.: Study of the hydrological relationship between Lake Ohrid and Prespa, Proc Symp Isotope Techn Water Res Dev. IAEA, Vienna, Austria, March 1991, 737-740, 1992.

Bard, E., Delaygue, G., Rostek, F., Antonioli, F., Silenzi, S., and Schrag, D.: Hydrological conditions in the western Mediterranean basin during the deposition of Sapropel 6 (ca. $175 \mathrm{kyr}$ ), Earth Planet. Sc. Lett., 202, 481-494, 2002.

Bar-Matthews, M., Ayalon, A., and Kaufmann, A.: Timing and hydrological conditions of sapropel events in the eastern Mediterranean, as evident from speleothems, Soreq cave, Israel, Chem. Geol., 169, 145-156, 2000.
Bar-Matthews, M., Ayalon, A., Gilmor, M., Matthews, A., and Hawkeshworth, C. J.: Sea-land oxygen isotopic relationships from planktonic foraminifera and speleothems in the Eastern Mediterranean region and their implication for paleorainfall during interglacial intervals, Geochim. Cosmochim. Ac., 67, 31813199, 2003.

Baumgarten, H., Wonik, T., Tanner, D. C., Francke, A., Wagner, B., Zanchetta, G., Sulpizio, R., Giaccio, B., and Nomade, S.: Age-depth model of the past $630 \mathrm{kyr}$ for Lake Ohrid (FYROM/Albania) based on cyclostratigraphic analysis of downhole gamma ray data, Biogeosciences, 12, 7453-7465, doi:10.5194/bg-12-7453-2015, 2015.

Berger, A. and Loutre, M. F.: Insolation values for the climate of the last 10 million years, Quaternary Sci. Rev., 10, 297-317, 1991.

Blaauw, M.: Out of tune: the dangers of aligning proxy archives, Quaternary Sci. Rev., 36, 38-49, 2012.

Blockley, S., Rasmussen, S. O., Harding, P., Brauer, A., Davies, S., Hardiman, M., Lane, C., Macleod, A., Matthews, I., Wulf, S., and Zanchetta G.: Tephrochronology and the extended INTIMATE (Integration of ice-core, marine and terrestrial records) event stratigraphy 8-110 ka B2K, Quaternary Sci. Rev., 106, 88100, 2014.

Brauer, A., Allen, J. R. M., Mingram, J., Dulski, P., Wulf, S., and Huntley, B.: Evidence for last interglacial chronology and environmental change from Southern Europe, P. Natl. Acad. Sci. USA, 104, 450-455, 2007.

Broecker, W. S. and van Donk, J.: Insolation changes, ice volume, and the o18 record in deep-sea cores, Rev. Geophys., 8, 169-198, 1970.

Boch, R., Cheng, H., Spötl, C., Edwards, R. L., Wang, X., and Häuselmann, Ph.: NALPS: a precisely dated European climate record 120-60 ka, Clim. Past, 7, 1247-1259, doi:10.5194/cp-71247-2011, 2011.

Caron, B., Sulpizio, R., Zanchetta, G., Siani, G., and Santacroce, R.: The Late Holocene to Pleistocene tephrostratigraphic record of lake Orhid (Albania), C. R. Geosci., 342, 453-466, 2010.

Damaschke, M., Sulpizio, R., Zanchetta, G., Wagner, B., Böhm, A., Nowaczyk, N., Rethemeyer, J., and Hilgers, A.: Tephrostratigraphic studies on a sediment core from Lake Prespa in the Balkans, Clim. Past, 9, 267-287, doi:10.5194/cp-9-267-2013, 2013.

Drysdale, R. N., Zanchetta, G., Hellstrom, J., Fallick, A. E., Zhao, J., Isola, I., and Bruschi, G.: The palaeoclimatic significance of a Middle to late Pleistocene stalagmite from the Alpi Apuane karst, central-western Italy, Earth Planet. Sc. Lett., 227, 215-229 2004.

Drysdale, R. N., Zanchetta, G., Hellstrom, J. C., Fallick, A. E., and Zhao, J.-X.: Stalagmite evidence for the onset of the Last Interglacial in southern Europe at $129 \pm 1 \mathrm{ka}$, Geophys. Res. Lett., 32, L24708, 2005.

Drysdale, R. N., Zanchetta, G., Hellstrom, J., Maas, R., Fallick, A. E., Pickett, M., Cartwright, I., and Piccini, L.: Late Holocene drought responsible for the collapse of Old World civilizations is recorded in an Italian cave flowstone, Geology, 34, 101-104, 2006.

Drysdale, R. N., Zanchetta, G., Hellstrom, J. C., Fallick, A. E., McDonald, J., and Cartwright, I.: Stalagmite evidence for the precise timing of North Atlantic cold events during the early last glacial, Geology, 35, 77-80, 2007. 
Drysdale, R. N., Hellstrom, J. C., Zanchetta, G., Fallick, A. E., Sánchez Goñi, M. F., Couchoud, I., McDonald, J., Maas, R., Lohmann, G., and Isola, I.: Evidence for Obliquity Forcing of Glacial Termination II, Science, 325, 1527-1531, 2009.

Föller, K., Stelbrink, B., Hauffe, T., Albrecht, C., and Wilke, T.: Constant diversification rates of endemic gastropods in ancient Lake Ohrid: ecosystem resilience likely buffers environmental fluctuations, Biogeosciences, 12, 7209-7222, doi:10.5194/bg12-7209-2015, 2015.

Francke, A., Wagner, B., Just, J., Leicher, N., Gromig, R., Vogel, H., Baumgarten, H., Lacey, J. H., Zanchetta, G., Sulpizio, R., Giacco, B., Wonik, T., and Leng, M. J.: Sedimentological processes and environmental variability at Lake Ohrid (Macedonia, Albania) between $640 \mathrm{ka}$ and modern days, Biogeosciences, 12, 15111-15156, doi:10.5194/bgd-12-15111-2015, 2015.

Francke, A., Wagner, B., Just, J., Leicher, N., Gromig, R., Baumgarten, H., Vogel, H., Lacey, J. H., Sadori, L., Wonik, T., Leng, M. J., Zanchetta, G., Sulpizio, R., and Giaccio, B.: Sedimentological processes and environmental variability at Lake Ohrid (Macedonia, Albania) between $637 \mathrm{ka}$ and the present, Biogeosciences, 13, 1179-1196, doi:10.5194/bg-13-1179-2016, 2016.

Giaccio, B., Regattieri, E., Zanchetta, G., Nomade, S., Renne, P. R., Sprain, C. J., Drysdale, R. N., Tzedakis, P. C., Messina, P., Scardia, G., Sposato, A., and Bassinot, F.: Duration and dynamics of the best orbital analogue to the present interglacial, Geology, 43, 603-606, 2015.

Govin, A., Capron, E., Tzedakis, P. C., Verheyden, S., Ghaleb, B., Hillaire-Marcel, C., St-Onge, G., Stoner, J. S., Bassinot, F., Bazin, L., Blunier, T., Combourieu-Nebout, N., El Ouahabi, A., Genty, D., Gersonde, R., Jimenez-Amat, P., Landais, A., Martrat, B., Masson-Delmotte, V., Parrenin, F., Seidenkrantz, M.-S., Veres, D., Waelbroeck, C., and Zahn, R.: Variations in the Eart's Orbit: Pacemaker of the Ice Age, Quaternary Sci. Rev., 129, 136, 2015.

Grant, K. M., Rohling, E. J., Bar-Matthews M., Ayalon A., MedinaElizalde, M., Bronk Ramsey, C., Satow, C., and Roberts A. P.: Rapid coupling between ice volume and polar temperature over the past 150000 years, Nature, 491, 744-747, 2012.

Hays, J. D., Imbrie, J., and Shackleton, N. J.: Variations in the Earth's Orbit: Pacemaker of the Ice Ages For 500000 years, major climatic changes have followed variations in obliquity and precession, Science, 194, 1121-1132, 1976.

Hodell, D., Crowhurst, S., Skinner, L., Tzedakis, P. C., Margari, V., Channell, J. E., Kamenov, G., Maclachlan, S., and Rothwell, G.: Response of Iberian Margin sediments to orbital and suborbital forcing over the past $420 \mathrm{ka}$, Paleoceanography, 28, 185199, 2013

Iorio, M., Liddicoat, J., Budillon, F., Incoronato, A., Coe, R. S., Insinga, D., Cassata, W. S., Lubritto, C., Angelino, A., and Tamburrino, S.: Combined palaeomagnetic secular variation and petrophysical records to time constrain geological and hazardous events: an example from the eastern Tyrrhenian Sea over the last $120 \mathrm{ka}$, Global Planet. Change, 113, 91-109, 2014.

Jiménez-Amat, P. and Zahn, R.: Offset Timing of Climate Oscillations During the Last two Glacial-Interglacial Transitions Connected with Large-Scale Freshwater Perturbation, Paleoceanography, 30, 768-788, 2015.

Just, J., Nowaczyk, N. R., Sagnotti, L., Francke, A., Vogel, H., Lacey, J. H., and Wagner, B.: Environmental control on the oc- currence of high-coercivity magnetic minerals and formation of iron sulfides in a $640 \mathrm{ka}$ sediment sequence from Lake Ohrid (Balkans), Biogeosciences, 13, 2093-2109, doi:10.5194/bg-132093-2016, 2016.

Kukla, G. J., Bender, M. L., de Beaulieu, J.-L., Bond, G., Broecker, W. S., Cleveringa, P., Gavin, J. E., Herbert, T. D., Imbrie, J., Jouzel, J., Keigwin, L. D., Knudsen, K.-L., McManus, J. F.; Merkt, J., Muhs, D. R., Muller, H., Poore, R. Z., Porter, S. C., Seret, G., Shackleton, N. J., Turner, C., Tzedakis, P. C., and Winograd, I J.: Last Interglacial Climates, Quaternary Res., 58, 2-13, 2002.

Lacey, J. H., Leng, M. J., Francke, A., Sloane, H. J., Milodowski, A., Vogel, H., Baumgarten, H., Zanchetta, G., and Wagner, B.: Northern Mediterranean climate since the Middle Pleistocene: a $637 \mathrm{ka}$ stable isotope record from Lake Ohrid (Albania/Macedonia), Biogeosciences, 13, 1801-1820, doi:10.5194/bg-13-1801-2016, 2016.

Leicher, N., Zanchetta, G., Sulpizio, R., Giaccio, B., Wagner, B., Nomade, S., Francke, A., and Del Carlo, P.: First tephrostratigraphic results of the DEEP site record from Lake Ohrid (Macedonia and Albania), Biogeosciences, 13, 2151-2178, doi:10.5194/bg-13-2151-2016, 2016.

Lézine, A.-M., von Grafenstein, U., Andersen, N., Belmecheri, S., Bordon, A., Caron, J., Cazet, P., Erlenkeuser, H., Fouache, E., Grenier, C., Huntsman-Mapila, P., Hureau-Mazaudier, D., Manelli, D., Mazaud, A., Robert, C., Sulpizio, R., Tiercelin, J.-J., Zanchetta, G., and Zeqollari Z.: Lake Ohrid, Albania, provides an exceptional multi-proxy record of environmental changes during the last glacial-interglacial cycle, Palaeogeogr. Palaeocl., 287, 116-127, 2010.

Lindhorst, K., Krastel, S., Reicherter, K., Stipp, M., Wagner, B., and Schwenk, T.: Sedimentary and tectonic evolution of Lake Ohrid (Macedonia/Albania), Basin Res., 27, 84-101, doi:10.1111/bre.12063, 2015.

Lisiecki L. E. and Raymo M. E.: A Pliocene-Pleistocene stack of 57 globally distributed benthic $\delta^{18} \mathrm{O}$ records, Paleoceanography, 20, PA1003, doi:10.1029/2004PA001071, 2005.

Lowe, D. L.: Tephrochronology and its application: a review, Quat. Geochronol., 6, 107-153, 2011

Marino, G., Rohling, E. J., Rodrìguez-Sanz, L., Grant, K. M., Heslop, D., Roberts, A. P., Stanford, J. D., and Yu, J.: Bipolar seesaw control on last interglacial sea level, Nature, 197, 197-201, 2015.

Martinson, D. G., Pisias, N. G., Hays, J. D., Imbrie, J., Moore Jr., T. C., and Shackleton, N. J.: Age dating and the orbital theory of the ice ages: Development of a high-resolution 0 to 300 000-year chronostratigraphy, Quaternary Res., 27, 1-29, 1987.

Martrat, B., Jimenez-Amat, P., Zahn, R., and Grimaltm J. O.: Similarities and dissimilarities between the last two deglaciations and interglaciations in the North Atlantic region, Quaternary Sci. Rev., 99, 122-134, 2014.

Matzinger, A., Spirkovski, Z., Patceva, S., and Wüest, A.: Sensitivity of ancient Lake Ohrid to local anthropogenic impacts and global warming, J. Great Lakes Res., 32 158-179, 2006.

Matzinger, A., Schmid, M., Veljanoska-Sarafiloska, E., Patceva, S., Guseska, D., Wagner, B., Müller, B., Sturm, M., and Wüest, A.: Eutrophication of ancient Lake Ohrid: global warming amplifies detrimental effects of increased nutrient inputs, Limnol. Oceanogr., 52, 338-353, 2007. 
Milner, A. M., Collier, R. E. L., Roucoux, K. H., Müller, U. C., Pross, J., Kalaitzidis, S., Christanis, K., and Tzedakis, P. C.: Enhanced seasonality of precipitation in the Mediterranean during the early part of the Last Interglacial, Geology, 40, 919-922, 2012.

Milner, A. M., Müller, U. C., Roucoux, K. H., Collier, R. E. L., Pross, J., Kalaitzidis, S., Christanis, K., and Tzedakis, P. C.: Environmental variability during the Last Interglacial: A new highresolution pollen record from Tenaghi Philippon, Greece, J. Quaternary Sci., 28, 113-117, 2013.

Paterne, M., Guichard, F., Duplessy, J. C., Siani, G., Sulpizio, R., and Labeyrie, J.: A 90000-200000 yrs marine tephra record of Italian volcanic activity in the Central Mediterranean Sea, J. Volcanol. Geoth. Res., 177, 187-196, 2008.

Popovska, C. and Bonacci, O.: Basic data on the hydrology of Lakes Ohrid and Prespa, Hydrol. Process., 21, 658-664, 2007.

Pross, J., Koutsodendris, A., Christanis, K., Fischer, T., Fletcher, W. J., Hardiman, M., Kalaitzidis, S., Knipping, M., Kotthoff, U., Milner, A. M., Müller, U. C., Schmiedl, G., Siavalas, G., Tzedakis, P. C., and Wulf, S.: The 1.35-Ma-long terrestrial climate archive of Tenaghi Philippon, northeastern Greece: Evolution, exploration, and perspectives for future research, Newsl. Stratigr., 48, 253-276, 2015.

Railsback, R. B., Gibbard, P. L., Head, M. J., Voarintsoa, N. R. G., and Toucanne, S.: An optimized scheme of lettered marine isotope substages for the last 1.0 million years, and the climatostratigraphic nature of isotope stages and substages, Quaternary Sci. Rev., 111, 94-106, 2015.

Regattieri, E., Zanchetta, G., Drysdale, R. N., Isola, I., Hellstrom, J. C., and Roncioni, A.: A continuous stable isotope record from the penultimate glacial maximum to the Last Interglacial (159$121 \mathrm{ka}$ ) from Tana Che Urla Cave (Apuan Alps, central Italy), Quaternary Res., 82, 450-461, 2014.

Regattieri, E., Giaccio, B., Zanchetta, G., Drysdale, R. N., Galli, P., Nomade, S., Peronace, E., and Wulf, S.: Hydrological variability over the Apennines during the Early Last Glacial precession minimum, as revealed by a stable isotope record from Sulmona basin, Central Italy, J. Quaternary Sci., 30, 19-31, 2015.

Regattieri, E., Giaccio, B., Galli, P., Nomade, S., Peronace, E., Messina P., Sposato, A., Boschi, C., and Gemelli, M.: A multiproxy record of MIS 11-12 deglaciation and glacial MIS 12 instability from the Sulmona Basin (central Italy), Quaternary Sci. Rev., 32, 129-145, 2016.

Rotolo, S. G., Scaillet, S., La Felice, S., and Vita-Scaillet, G.: A revision of the structure and stratigraphy of pre-Green Tuff ingimbrites at Pantelleria (Strait of Sicily), J. Volcanol. Geoth. Res., 250, 61-74, 2013.

Sadori, L., Koutsodendris, A., Panagiotopoulos, K., Masi, A., Bertini, A., Combourieu-Nebout, N., Francke, A., Kouli, K., Joannin, S., Mercuri, A. M., Peyron, O., Torri, P., Wagner, B., Zanchetta, G., Sinopoli, G., and Donders, T. H.: Pollen-based paleoenvironmental and paleoclimatic change at Lake Ohrid (south-eastern Europe) during the past $500 \mathrm{ka}$, Biogeosciences, 13, 1423-1437, doi:10.5194/bg-13-1423-2016, 2016.

Sánchez-Goñi, M., Eynaud, F., Turon, J., and Shackleton, N.: High resolution palynological record off the Iberian margin: direct land-sea correlation for the Last Interglacial complex, Earth Planet. Sc. Lett., 171, 123-137, 1999.
Sánchez-Goñi, M. F., Bard, E., Landais, A., Rossignol, L., and d'Errico F.: 2013 Air-sea temperature decoupling in western Europe during the last interglacial-glacial Transition, Nat. Geosci., 6, 837-841, 2013.

Satow, C., Tomlinson, E. L., Grant, K. M., Albert, P. G., Smith, V. C., Manning, C. J., Ottolini, L., Wulf, S., Rohling, E. J., Lowe, J. J., Blockley, S. P. E, and Menzies, M. A.: A new contribution to the Late Quaternary tephrostratigraphy of the Mediterranean: Aegean Sea core LC21, Quaternary Sci. Rev., 117, 96-112, 2015.

Shackleton, N. J.: Oxygen isotopes, ice volume and sea level, Quaternary Sci. Rev. 6, 183-190, 1987.

Shackleton, N. J.: The 100 000-Year Ice-Age Cycle Identified and Found to Lag Temperature, Carbon Dioxide, and Orbital Eccentricity, Science, 289, 1897-1902, 2000.

Shackleton, N. J., Sánchez-Goñi, M.F, Pailler, D, Lancelot Y.: Marine Isotope Substage 5e and the Eemian Interglacial, Global Planet. Change, 36, 151-155, 2003.

Stankovic, S.: The Balkan Lake Ohrid and Its Living World, Uitgeverij Dr. W. Junk, Den Haag, 1960.

Skinner, L. C. and Shackleton, N. J.: Deconstructing Terminations I and II: revisiting the glacioeustatic paradigm based on deepwater temperature estimates, Quaternary Sci. Rev., 25, 33123321, 2006.

Sprovieri, R., Di Stefano, E., Incarbona, A., and Oppo, D. W.: Suborbital climate variability during Marine Isotopic Stage 5 in the central Mediterranean basin: evidence from calcareous plankton record, Quaternary Sci. Rev., 25, 2332-2342, 2006.

Sulpizio, R., van Welden, A., Caron, B., and Zanchetta, G.: The Holocene tephrostratigraphy of Lake Shkodra (Albania and Montenegro), J. Quaternary Sci., 25, 633-650, 2010a.

Sulpizio, R., Zanchetta, G., D’Orazio, M., Vogel, H., and Wagner, B.: Tephrostratigraphy and tephrochronology of lakes Ohrid and Prespa, Balkans, Biogeosciences, 7, 3273-3288, doi:10.5194/bg7-3273-2010, 2010b.

Tamburrino, S., Insinga, D., Sprovieri, M., Petrosino, P., and Tiepolo, M.: Major and trace element characterization of tephra layers offshore Pantelleria Island: insights into the last $200 \mathrm{ka}$ of volcanic activity and contribution to the Mediterranean tephrochronology, J. Quaternary Sci., 27, 129-140, 2012.

Trajanovski, S., Albrecht, C., Schreiber, K., Schultheiß, R., Stadler, T., Benke, M., and Wilke, T.: Testing the spatial and temporal framework of speciation in an ancient lake species flock: the leech genus Dina (Hirudinea: Erpobdellidae) in Lake Ohrid, Biogeosciences, 7, 3387-3402, doi:10.5194/bg-7-3387-2010, 2010.

Tzedakis, P. C., Andrieu, V., de Beaulieu, J.-L., Crowhurst, S., Follieri, M., Hooghiemstra, H., Magri, D., Reille, M., Sadori, L., Shackleton, N. J., and Wijmstra, T. A.: Comparison of terrestrial and marine records of changing climate of the last 500000 years, Eerth Planet. Sc. Lett., 150, 171-176, 1997.

Tzedakis, P. C., Andrieu, V., Birks, H. J. B., de Beaulieu, J.-L., Crowhurst, S., Follieri, M., Hooghiemstra, H., Magri, D., Reille, M., Sadori, L., Shackleton, N. J., and Wijmstra, T. A.: Establishing a terrestrial chronological framework as a basis for biostratigraphical comparisons, Quaternary Sci. Rev., 20, 1583-1592, 2001.

Tzedakis, P. C., Frogley, M. R., and Heaton, T. H. E.: Last Interglacial conditions in southern Europe: evidence from Ioannina, northwest Greece, Global Planet. Change, 36, 157-170, 2003. 
Tzedakis, P. C., Hooghiemstra, H., and Pälike, H.: The last 1.35 million years at Tenaghi Philippon: revised chronostratigraphy and long-term vegetation trends, Quaternary Sci. Rev., 25, 34163430, 2006.

Vogel, H., Zanchetta, G., Sulpizio, R., Wagner, B., and Nowaczyk, N.: A tephrostratigraphic record for the last glacial-interglacial cycle from Lake Ohird, Albania and Macedonia, J. Quaternary Sci., 25, 320-338, 2010.

Waelbroeck, C., Labeyrie, L., Michel, E., Duplessy, J. C., McManus, J. F., Lambeck, K., Balbon, E., and Labracherie, M.: Sealevel and deep water temperature changes derived from benthic foraminifera isotopic records, Quaternary Sci. Rev., 21, 295-305, 2002.

Wagner, B., Sulpizio, R., Zanchetta, G., Wulf, S., Wessels, M., Daut, G., and Nowaczyk, N.: The last 40 ka tephrostratigraphic record of Lake Ohrid, Albania and Macedonia: a very distal archive for ash dispersal from Italian volcanoes, J. Volcanol. Geoth. Res., 177, 71-80, 2008.

Wagner, B., Wilke, T., Krastel, S., Zanchetta, G., Sulpizio, R., Reicherter, K., Leng, M. J., Grazhdani, A., Trajanovski, S., Francke, A., Lindhorst, K., Levkov, Z., Cvetkoska, A., Reed, J. M., Zhang, X., Lacey, J. H., Wonik, T., Baumgarten, H., and Vogel, H.: The SCOPSCO drilling project recovers more than 1.2 million years of history from Lake Ohrid, Sci. Dril., 17, 19-29, doi:10.5194/sd-17-19-2014, 2014a.

Wagner, B., Wilke, T., Krastel, S., Zanchetta, G., Sulpizio, R., Reicherter, K., Leng, M., Grazhdani, A., Trajanovski, S., Levkovm Z., Reed, J., and Wonik T.: More than one Million years of History of Lake Ohrid cores, EOS, 95, 25-32, 2014b.

Watzin, M. C., Puka, V., and Naumoski, T. B.: Lake Ohrid and its Watershed, State of the Environment Report, Lake Ohrid Conservation Project, Tirana, Albania and Ohrid, Macedonia, 2002.

Wilson, G. P., Reed, J. R., Frogley, M. R., Hughes, P. D., and Tzedakis, P. C.: Reconciling diverse lacustrine and terrestrial system response to penultimate deglacial warming in southern Europe, Geology, 43, 819-822, 2015.

Wulf, S., Kraml, M., Brauer, A., Keller, J., and Negendank, J. F. W.: Tephrochronology of the $100 \mathrm{ka}$ lacustrine sediment record of Lago Grande di Monticchio (southern Italy), Quatern. Int. 122, 7-30, 2004.
Wulf, S., Kraml, M., and Keller, J.: Towards a detailed distal tephrostratigraphy in the Central Mediterranean: the last 20000 yrs record of Lago Grande di Monticchio, J. Volcanol. Geoth. Res. 177, 118-132, 2008.

Zanchetta, G., Sulpizio, R., Giaccio, B., Siani, G., Paterne, M., Wulf, S., and D'Orazio, M.: The Y-3 tephra: a Last Glacial stratigraphic marker for the central Mediterranean basin, J. Volcanol. Geoth. Res., 177, 145-154, 2008.

Zanchetta, G., Sulpizio, R., Roberts, N., Cioni, R., Eastwood, W. J., Siani, G., Caron, B., Paterne, M., and Santacroce, R.: Tephrostratigraphy, chronology and climatic events of the Mediterranean basin during the Holocene: An overview, Holocene, 21, 33-52, 2011.

Zanchetta, G., Giraudi, C., Sulpizio, R., Magny, M., Drysdale, R. N., and Sadori L.: Constraining the onset of the Holocene "Neoglacial" over the central Italy using tephra layers, Quaternary Res., 78, 236-247, 2012a.

Zanchetta, G., van Welden, A., Baneschi, I., Drysdale, R. N., Sadori, L., Roberts, N., Giardini, M., Beck, C., and Pascucci, V.: Multiproxy record for the last 4500 years from Lake Shkodra (Albania/Montenegro), J. Quaternary Sci., 27, 780-789, 2012b.

Zanchetta, G., Bar-Matthews, M., Drysdale, R. N., Lionello, P., Ayalon, A., Hellstrom, J. C., Isola, I., and Regattieri, E.: Coeval dry events in the central and eastern Mediterranean basin at 5.2 and $5.6 \mathrm{ka}$ recorded in Corchia (Italy) and Soreq Cave (Israel) speleothems, Global Planet. Change, 122, 130-139, 2014.

Zhornyak, L. V., Zanchetta, G., Drysdale, R. N., Hellstrom, J. C., Isola, I., Regattieri, E., Piccini, L., and Baneschi I.: Stratigraphic evidence for a "pluvial phase" between ca. 8200-7100 ka from Renella Cave (Central Italy), Quaternary Sci. Rev., 30, 409-417, 2011.

Ziegler, M., Tuenter, E., and Lourens, L. J.: The precession phase of the boreal summer monsoon as viewed from the eastern Mediterranean (ODP Site 968), Quaternary Sci. Rev., 29, 1481-1490, 2010 . 